\title{
Knowledge Sharing Mahasiswa KKM Melalui Pemanfaatan Limbah Kertas Menjadi Kerajinan Tangan
}

\author{
Eka Indah Yuslistyari, Gina Ramayanti, Hany Azza Umama, Meassa Monikha Sari, \\ Ade Agus Surya, Reza Sakti \\ Universitas Serang Raya \\ ekaindah82@yahoo.co.id
}

Submitted: $31^{\text {st }}$ July 2019. Revised: $11^{\text {th }}$ October 2019. Accepted: $31^{\text {st }}$ October 2019

\section{Key word:}

Kuliah Kerja

Mahasiswa

(KKM);

Knowledge

Sharing; Waste

Paper;

Entrepreneurship

\section{Kata Kunci}

Kuliah Kerja

Mahasiswa,;

Knowledge

Sharing;

Limbah Kertas;

Wirausaha

\section{Abstract}

Kuliah kerja masyarakat (KKM) years 2019 raised the subject of community empowerment through the development of creative economy. Most of student do not have enough knowledge in the determination of the work program to be applied in the community activities in the kuliah kerja masyarakat (KKM), no shortage of waste paper, the local currency must be entrepreneurs on college students in utilization of waste as yet there is no. Objectives of the activities devotion through knowledge sharing to students through the utilization of waste paper to become how to make handicrafts including providing knowledge and skills and to improve entrepreneurial interest through the use of waste paper to students. The importance of activites is knowledge sharing. Participants activities of are KKM students in kecamatan Cikeusal and kecamatan Ciomas. Activities started by observation this field to find the problems that arise implementation are the next stage of the preparation of materials and practice making handicrafts. The results are knowledge sharing that took place to students able to provide understanding as provisions in empowering community. Through the knowledge sharing, KKM students increase skill development have especially in any by elementary substance waste paper to handicrafts. The outer covering this activity is the product handicrafts with basic made waste paper that is tissue box.

\section{Abstrak}

Kuliah Kerja Mahasiswa (KKM) Tahun 2019 mengangkat topik pemberdayaan masyarakat melalui pembangunan ekonomi kreatif. Permasalahan yang terjadi diantaranya mahasiswa belum memiliki cukup pengetahuan dalam penentuan program kerja yang akan diterapkan di masyarakat pada kegiatan Kuliah Kerja Masyarakat (KKM), melimpahnya limbah kertas, selain itu minat wirausaha pada mahasiswa dalam pemanfaatan limbah belum ada. Tujuan kegiatan pengabdian melalui knowledge sharing kepada mahasiswa KKM melalui pemanfaatan limbah kertas untuk menjadi kerajinan tangan diantaranya memberikan pengetahuan dan keterampilan serta menumbuhkan minat wirausaha melalui pemanfaatan limbah kertas bagi mahasiswa. Pentingnya kegiatan knowledge sharing diberikan kepada mahasiswa sebagai bekal dalam program pemberdayaan masyarakat. Peserta kegiatan diantaranya mahasiswa KKM di kecamatan Cikeusal dan kecamatan Ciomas yaitu kelompok 26, 36 dan 70. Pelasanaan kegiatan ini diawali dengan 
observasi lapangan untuk menemukan masalah yang muncul di masyarakat. Tahap selanjutnya yaitu implementasi diantaranya persiapan bahan dan praktek pembuatan kerajinan tangan. Hasil yang diperoleh yaitu kegiatan knowledge sharing yang dilaksanakan kepada mahasiswa KKM mampu memberikan pemahaman sebagai bekal dalam pemberdayaan masyakat. Melalui program knowledge sharing, mahasiswa KKM menperoleh peningkatan keterampilan khususnya dalam pengembangan produk dengan bahan dasar limbah kertas menjadi kerajinan tangan. Luaran kegiatan ini adalah produk kerajinan tangan dengan berbahan dasar limbah kertas yaitu kotak tisu.

\section{PENDAHULUAN}

Tri Dharma Perguruan Tinggi diantaranya yaitu dharma pengajaran, penelitian dan pengabdian masayarakat. Perguruan tinggi berkewajiban menyelenggarakan penelitian dan pengabdian kepada masayarakat disamping melaksanakan pendidikan sebagaimana diamanahkan oleh Undang-Undang Nomor 20 Tahun 2003 tentang "Sistem Pendidikan Nasional Pasal 20", selain itu UndangUndang Nomor 12 Tahun 2012 tentang "Pendidikan Tinggi Pasal 45" menegaskan bahwa penelitian di perguruan tinggi diarahkan untuk mengembangkan ilmu pengetahuan dan teknologi serta meningkatkan kesejahteraan masyarakat dan daya saing bangsa (Direktorat Riset dan Pengabdian Masyarakat, 2018). Salah satu kegiatan pengabdian masyarakat yang dilaksanakan oleh perguruan tinggi yaitu kuliah kerja masyarakat (KKM).

Kuliah Kerja Masyarakat (KKM) merupakan mata kuliah wajib oleh mahasiswa Program Strata Satu (S1) berupa kuliah kerja yang dilakukan mahasiswa di masyarakat sebagai bentuk pelaksanaan Tri Dharma Perguruan Tinggi. KKM bertujuan untuk meningkatkan pemahaman mahasiswa atas peran serta dalam masyarakat melalui tambahan wawasan, pengetahuan, keterampilan, dan kemampuan bermasyarakat.Kelompok KKM tiap kecamatan terdiri dari 12 kelompok yang ditempatkan di masingmasing desa yang ditentukan sebelumnya. Untuk meningkatkan pemahaman bagi mahasiswa tentunya diperlukan pembekalan sebelum melaksanakan KKM.

Permasalahan yang terjadi diantaranya mahasiswa belum memiliki cukup pengetahuan dalam penentuan program kerja yang akan diterapkan di masyarakat pada kegiatan Kuliah Kerja Masyarakat (KKM). Persoalan lain yang dihadapi mahasiswa setelah menyelesaikan tugas, banyak kertas tidak terpakai sehingga menjadi limbah. Selain itu minat wirausaha dalam pemanfaatan limbah belum ada.

Limbah merupakan hal kecil yang sering dilupakan, namun bisa menjadi masalah yang besar apabila tidak ditangani secara serius. Dalam hal ini limbah kertas 
merupakan masalah utama yang sering ditemui masyarakat, dikarenakan kertas merupakan benda yang paling banyak digunakan masyarakat dan tentunya paling banyak dibuang dan menghasilkan limbah. Berbagai jenis kertas seperti koran-koran atau brosur- brosur, yang sudah tidak terpakai dibiarkan menumpuk begitu saja atau bahkan dibuang sembarangan.Saat ini kertas sudah menjadi suatu kebutuhan penting dalam kehidupan sehari-hari seperti menulis, mencetak ataupun membungkus. Dari aktivitas yang dijalankan seringkali kertas tidak terpakai yang akhirnya menjadi limbah. Sepertinya, limbah kertas ini memang terlihat tidak terlalu berat. Akan tetapi limbah kertas ini seringkali kita temukan dirumah, perkantoran, percetakan, dan sekolah bahkan mahasiswa kerap kali menggunakan kertas untuk mengerjakan tugas kuliah serta yang banyak mengakibatkan melimpahnya limbah kertas.

Limbah kertas merupakan salah satu masalah yang terdapat dalam lingkungan. Hal ini disebabkan masih sedikit kesadaran untuk menanggulangi limbah kertas tersebut. Sikap individu yang cenderung tidak peduli dengan kesehatan lingkungan inilah yang menjadi penyebab pencemaran lingkungan terus terjadi. Kurangnya pengetahuan mengenai dampak yang akan ditimbulkan limbah kertas dalam lingkungan juga menjadi salah satu faktorpendukungnya. Untuk itu diperlukan pematangan sosialisasi serta pendidikan tentang pengolahan limbah serta berbagai tindakan atau upaya menanggulangi limbah tersebut melalui kegiatan knowledge sharing kepada para mahasiswa KKM melalui pemanfaatan limbah kertas.

Tujuan kegiatan pengabdian melalui knowledge sharingkepada mahasiswa KKM melalui pemanfaatan limbah kertas untuk menjadi kerajinan tangan diantaranya memberikan pengetahuan dan keterampilan serta menumbuhkan minat wirausaha melalui pemanfaatan limbah kertas bagi mahasiswa.Penumbuhan minat wirausaha tidak dapat dilakukan serta merta tanpa adanya pendidikan dan pelatihan yang dapat menggerakkan jiwa kewirausahaan seseorang (Rosmiati, Junias, Munawar, 2015).

Salah satu tujuan dari pembangunan nasional adalah pembangunan sumber daya manusia, baik laki-laki maupun perempuan (Yuslistyari \& Djamal, 2018). Pembangunan nasional sangat bertumpu kepada aktifitas ekonomi (wirausaha) yang dilakukan masyarakat pada umumnya. Untuk meningkatkan pembangunan nasional secara merata, diperlukan upaya 
dalam menurunkan tingkat kemiskinan di Indonesia.

Era digitalisasi ekonomi saat ini telah menggiringumat manusia dalam suatu interaksi sosial akibatpenemuan baru dalam bidang teknologi dan informasi. Tuntutan keunggulan kreasi dan inovasi dalam aktifitas ekonomi merupakan suatu kreatif yang bertumpu pada pengetahuan dan menyanggupi untuk melakukan suatu pekerjaan kreatifitas masyarakat wirausaha sebagai "nilai jual" sehingga mampu menjelma menjadi kekuatan baru dalam memenangkan kompetisi dan pengembangan ekonomi (Jonnius, 2013). Sinergi kewirausahaan dan industri kreatif merupakan upaya pengembangan yang saling melengkapi. (Priyono dan Muqorobin, 2012).

Kegiatan knowledge sharing ini untuk mempersiapkan program pengabdian yang akan dilaksanakan di kecamatan Cikeusal dan kecamatan Ciomas. Kelompok yang dipilih yaitu kelompok 26 dan 36 pada kecamatan Cikeusal dan kelompok 70 pada kecamatan Ciomas. Tiap kelompok terdiri dari 16 orang mahasiswa dari berbagai program studi di Universitas Serang Raya.

Desa Sukamaju dan Bantar Panjang merupakan desa di wilayah Kecamatan Cikeusal Kabupaten Serang Provinsi Banten, peta desa dapat dilihat pada
Gambar 1 dan Gambar 2. Desa Pondok Kahuru merupakan salah satu desa di wilayah Kecamatan Ciomas Kabupaten Serang Provinsi Banten, peta desa dapat dilihat pada Gambar 3.

Luas wilayah desa Sukamaju mencapai $\pm 210 \mathrm{Ha}$, terdiri dari lahan pemukiman, lahan pertanian, lahan perkebunan dan sisanya terdiri dari lahan peternakan, perkantoran, dan fasilitas umum lainnya. Secara demografis batas wilayah desa Sukamaju di sebelah utara berbatasan dengan desa Cilayang, sebelah selatan berbatasan dengan desa Cikeusal, sebelah barat berbatasan dengan desa Sukaraja dan sebelah timur berbatasan dengan desa Harundana dengan ketinggian sebesar 2.900 meter diatas permukaan laut. Berdasarkan data yang diperoleh melalui sukamajudesa.wordpress.com diakses 12 Agustus 2019, desa Sukamaju merupakan pemecahan wilayah desa Kalapadua. Nama sebutan sebelum dibentuk desa Sukamaju yaitu dusun Rancabolang. Jumlah penduduk desa Sukamaju terdiri atas 1.937 jiwa Laki-Laki dan 1.809 jiwa perempuan. Berdasarkan tingkat pendidikan yang paling banyak diantaranya lulusan Sekolah Dasar (SD) mencapai 107 orang, 59 orang lulus SLTP/MTs, 37 orang lulus SLTA, 10 orang lulus Diploma, 42 orang lulus S1. Mata pencaharian dominan di desa Sukamaju yaitu bertani dan berdagang, 
namun banyak pula yang menjadi pegawai negeri, TNI dan Polri bahkan beternak.

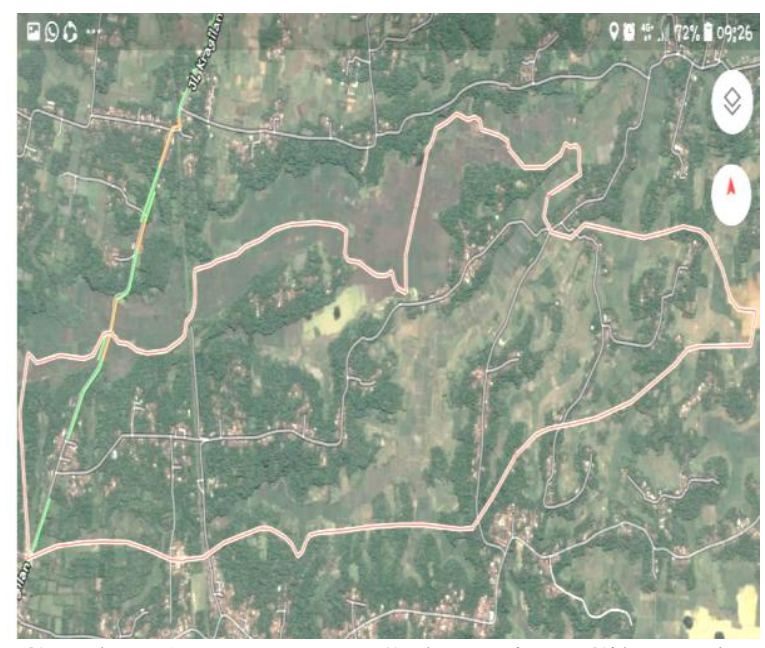

Gambar 1. Peta Desa Sukamaju - Cikeusal

Luas wilayah desa Bantar Panjang mencapai $\pm 2.836 \mathrm{Ha}$, didominasi oleh pemukiman sebesar $1360 \mathrm{Ha}$, fasilitas umum $1.124 \mathrm{Ha}$. pertanian $248 \mathrm{Ha}$, perkantoran $54 \mathrm{Ha}$, dan Perkebunan $50 \mathrm{Ha}$. Batas wilayah desa Bantar Panjang di sebelah utara berbatasan dengan desa Panosogan, sebelah selatan berbatasan dengan desa Dahu, sebelah barat berbatasan dengan desa Cikeusal dan sebelah timur berbatasan dengan desa Katulisan. Berdasarkan data yang diperoleh melalui kelurahan, jumlah penduduk desa Angsana terdiri atas 1.382 jiwa Laki-Laki dan 1.275 jiwa perempuan. Berdasarkan tingkat pendidikan yang paling banyak diantaranya lulusan SLTP mencapai 470 orang, adapun lulusan SD sebanyak 37 orang, SLTA sebanyak 330 orang dan Sarjana sebanyak 26 orang, bahkan terdapat sebanyak 145 orang tidak menyelesaikan pendidikan.

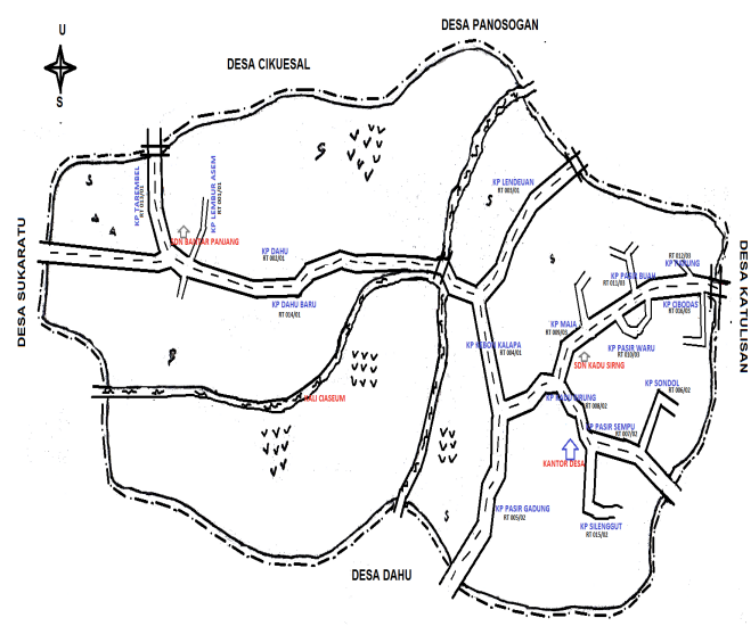

Gambar 2. Peta Desa Bantar PanjangCikeusal

Luas wilayah desa Pondok Kahuru mencapai $\pm 265 \mathrm{Ha}$, dimana $51 \&$ dari total luasnya adalah lahan perkebunan dan ladang. terdiri dari 57 Ha lahan pemukiman, $71 \mathrm{Ha}$ lahan pertanian, $133 \mathrm{Ha}$ lahan perkebunan dan sisanya terdiri dari lahan peternakan, perikanan, fasilitas umum dan fasilitas sosial. Secara demografis batas wilayah desa Pondok Kahuru di sebelah utara berbatasan dengan desa Ciomas, sebelah selatan berbatasan dengan desa Citaman, sebelah barat berbatasan dengan desa Labak dan sebelah timur berbatasan dengan desa Sukabares. Secara umum desa Pondok Kahuru merupakan daerah dataran tinggi dengan ketinggian 800 meter diatas permukaan laut. Dengan kontur jalan berbukit dan berkelok. Berdasarkan data yang diperoleh 
melalui situs

http://desapondokkahuru.blogspot.com, jumlah penduduk desa Pondok Kahuru terdiri atas 2.264 jiwa Laki-Laki dan 2.009 jiwa perempuan. Berdasarkan tingkat pendidikan 53\% dari seluruh total penduduk adalah tamatan Sekolah Dasar (SD). Selain pelajar dan tidak bekerja, mata pencaharian penduduk didominasi oleh buruh harian dan buruh tani.

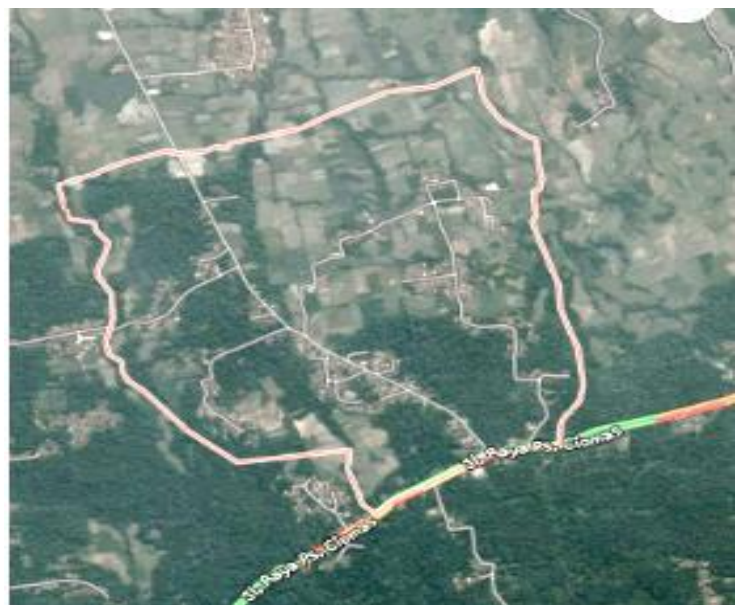

Gambar 3. Peta Desa Pondok Kahuru Ciomas

Kegiatan ekonomi desa Sukamaju, Bantar Panjang dan Pondok Kahuru masih didominasi oleh sektor pertanian dan perdagangan. Namun dari pesatnya pertanian desa belum seutuhnya membuahkan hasil optimal. Ini disebabkan karena masih rendahnya pengetahuan. Tingkat pendapatan masyarakat belum seutuhnya mencukupi kebutuhan hidup karena harga barang tidak sebanding dengan penghasilan yang didapat dikarenakan masih minimnya bekal ketrampilan, upah buruh yang masih kecil serta semakin mahalnya barang-barang kebutuhan sembako.

Salah satu cara meningkatkan perekonomian yaitu dengan mengembangkan home industry. Melalui pemanfaatan limbah kertas ini, dapat meningkatkan kewirausahaan di desa Sukamaju, Bantar Panjang, dan Pondok Kahuru. Mengingat pembangunan jalan tol yang beberapa waktu kedepan hamper rampung dan pemerintah pun mulai konsentrasi pada desa wisata Sukaratu.

\section{METODE}

Program pembekalan mahasiswa KKM ini dilaksanakan melalui tahapan kegiatan tahap awal, dan tahap implementasi diantaranya adalah :

\section{Tahap Awal}

Tahap ini dilakukan berupa studi lapangan dengan meninjau lokasi tempat KKM akan dilaksanakan sebagai kegiatan pengabdian oleh mahasiswa KKM yaitu Desa Sukamaju dan Desa Bantar Panjang Kecamatan Cikeusal, serta Desa Pondok Kahuru Kecamatan Ciomas. Pada tahap ini mahasiswa didampingi oleh dosen pembimbing lapangan melakukan observasi untuk menemukan masalah yang dihadapi oleh masyarakat.

\section{Tahap Implementasi}




\section{Dalam tahap implementasi ini HASIL}

terdiri dari :

\section{Persiapan bahan}

Pada tahap ini dilakukan kegiatan mempersiapkan bahan-bahan yang akan digunakan untuk tercapainya kegiatan pembekalan KKM kepada mahasiswa kelompok 26 dan 36 untuk kecamatan Cikeusal dan kelompok 70 untuk kecamatan Ciomas.

\section{Praktek Pembuatan Kerajinan Tangan}

Praktek pembuatan kerajinan tangan berbahan dasar limbah kertas dilakukan oleh tiga kelompok KKM yaitu kelompok 26 dan 36 dengan tempat pengabdian di kecamatan Cikeusal dan kelompok 70 dengan tempat pengabdian di kecamatan Ciomas yang dilaksanakan pada tangagal 29 Juli 2019. Mengenai waktu pelaksanaan praktek pembuatan kerajinan tangan ditentukan dengan kesepakatan seluruh kelompok.Tujuan dilaksanakannya kegiatan ini yaitu membekali mahasiswa sebelum melaksanakan KKM sebagai dasar mengembangkan kewirausahaan masyarakat melalaui pemberdayaan limbah kertas. Selanjutnya dapat mengembangkan produk yang memiliki nilai jual dalam rangka peningkatan perekonomian masyarakat.
Home industry di Kecamatan Ciomas dan Cikeusal bisa mendapat pemahaman baru tentang penggunaan limbah kertas melalui pengabdian masyarakat yang dilakukan dengan.

Kegiatan yang telah dilakukan dalam program pengabdian ini adalah:

1) Diskusi mengenai pemahaman fungsi limbah kertas; dan

2) Pelatihan pembuatan kerajinan tangan;

\section{PEMBAHASAN}

Program pengabdian kepada masyarakat melalui knowledge sharing kepada mahasiswa KKM di Kecamatan Ciomas dan Cikeusal berjalan dengan baik. Mahasiswa dapat meneruskan pemahaman yang mereka miliki untuk meningkatkan income bagi masyarakat di lokasi KKM. Hasil pengabdian dijelaskan sebagai berikut:

\section{Tahap Awal}

Tahap awal ini melakukan studi lapangan ke lokasi tempat kegiatan KKM akan dilaksanakan yaitu Desa Sukamaju dan Desa Bantar Panjang Kecamatan Cikeusal, serta Desa Pondok Kahuru Kecamatan Ciomas, Kabupaten Serang. Kemudian melakukan koordinasi dengan aparat desa diantaranya Camat dan Kepala Desa, Ketua RW, ketua RT serta para tokoh masyarakat guna kelancaran dalam 
memperoleh informasi dalam tercapainya tujuan akhir pengabdian. Selanjutnya merumuskan masalah dan solusi yang dihadapi oleh masyarakat dalam kaitannya dengan kewirausahaan. Silahturahmi kepada perangkat desa dapat dilihat pada Gambar 4 dan Gambar 5.

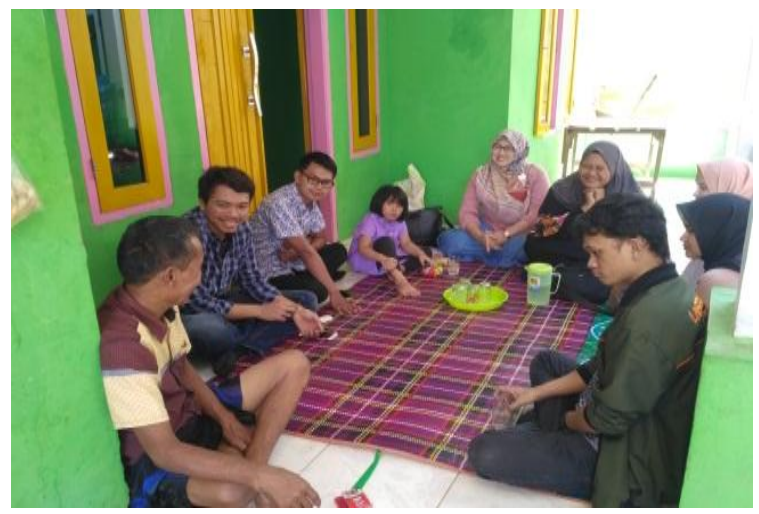

Gambar 4. Observasi Awal Silahturahmi Ketua RW

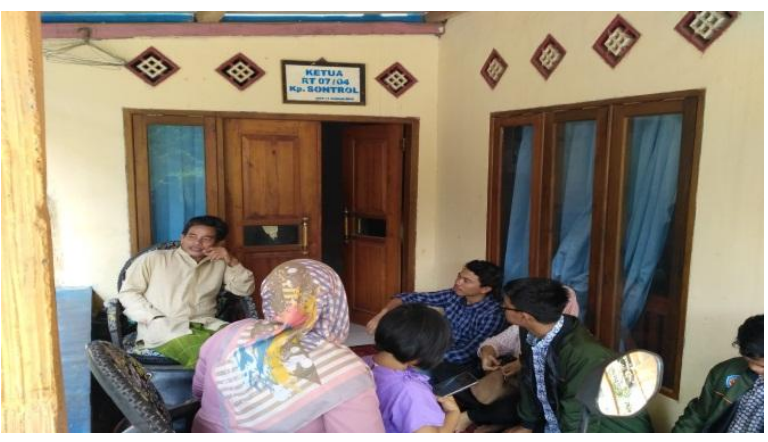

Gambar 5. Observasi awal silahturahmi ketua RT

Meninjau lokasi kegiatan dilaksanakan pada 16 Juli 2019 oleh peserta KKM kelompok 26 dan kelompok 36 di Kecamatan Cikeusal dan kelompok 70 dikecamatan Ciomas didampingi oleh 1 orang Dosen pembimbing lapangan di tiap kelompok. Selanjutnya peserta KKM menentukan waktu pelaksanaan pembekalan membuat kerajinan tangan dengan persetujuan seluruh dosen pembimbing.

\section{Tahap Implementasi}

\section{Persiapan Bahan}

Pada tahap ini dilakukan kegiatan persiapan bahan diantaranya menyiapkan bahan berupa kertas bekas pakai, kawat panjang untuk menggulung kertas, lem fox untuk menempelkan bagian kertas, lem tembak untuk menempelkan gulungan satu dengan lainnya, pulpen untuk membentuk gulungan kertas, pengaris dan gunting untuk memotong. Bahan-bahan disiapkan oleh dosen pembimbing lapangan dibantu oleh mahasiswa. Kegiatan persiapan bahan dilaksanakan pada tanggal 20 Juli 2019. Adapun bahan-bahan yang akan digunakan dalam pembuatan kerajinan tangan dapat dilihat pada Gambar 6.

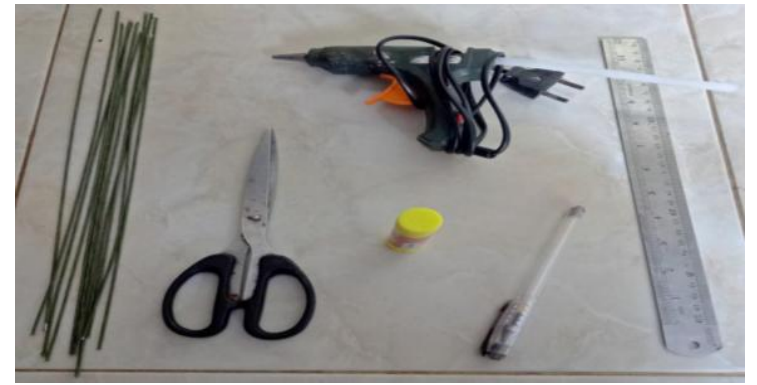

Gambar 6. Bahan yang digunakan

\section{Praktek Pembuatan Kerajinan Tangan}

Praktek pembuatan kerajinan tangan berbahan dasar limbah kertas ini dilaksanakan pada tanggal 29 Juli 2019 bertempat di gedung B Universitas Serang 
Raya. Peserta kegiatan yaitu para mahasiswa KKM kelompok 26, kelompok 36 dan kelompok 70 dihadiri oleh dosen pendamping lapangan KKM pada kecamatan Cikeusal dan Ciomas dapat dilihat pada Gambar 7.

Pada praktek pembuatan kerajinan tangan ini diawali dengan proses pengguntingan limbah kertas menjadi 2 bagian selanjutnya terlihat pada Gambar 8 . Kemudian dilanjutkan dengan proses penggulunganlimbah kertas yang dilem pada bagian ujungnya terlihat pada Gambar 9 dan hasil gulungan limbah kertas dapat dilihat pada Gambar 10.Untuk membuat satu bagian dari kerajinan tangan dilakukan perakitan pada gulungan-gulungan kertas yang sebelumnya di ukur terlebih dahulu. Kemudian rakit dengan menggunakan lem tembak.

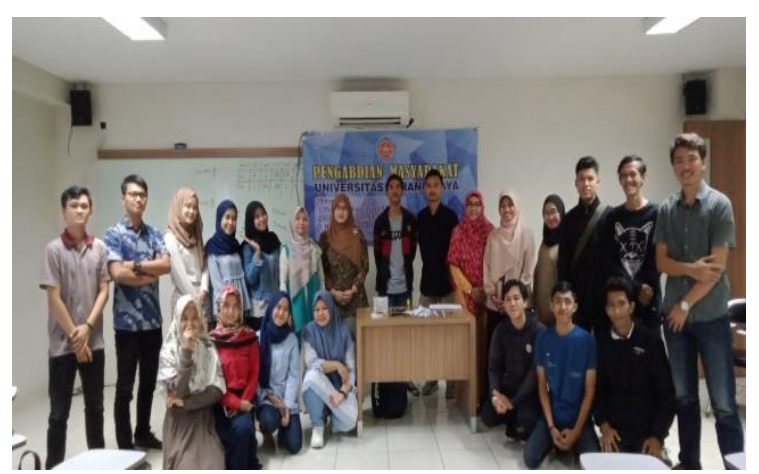

Gambar 7. Peserta kegiatan knowledge sharing

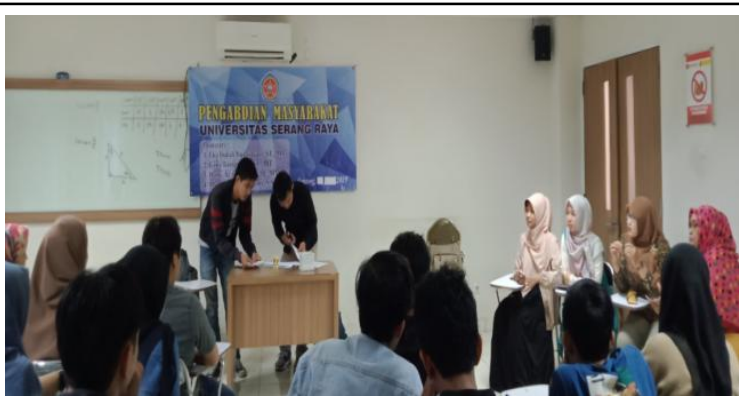

Gambar 8. Proses pengguntingan limbah kertas

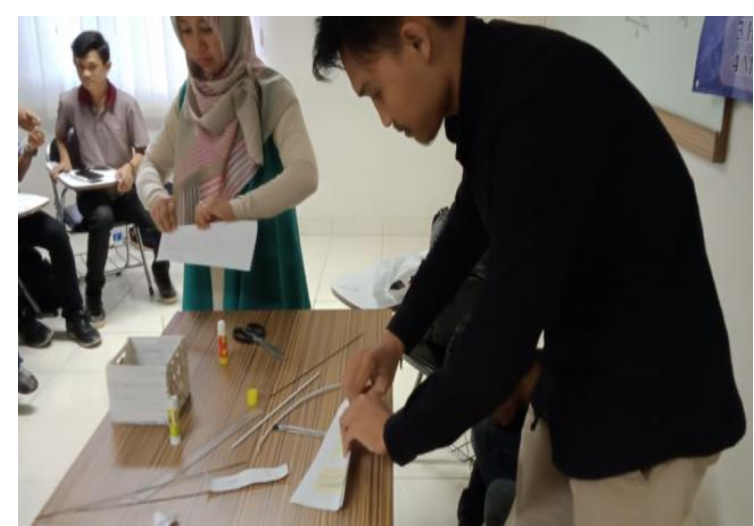

Gambar 9. Proses penggulungan limbah kertas

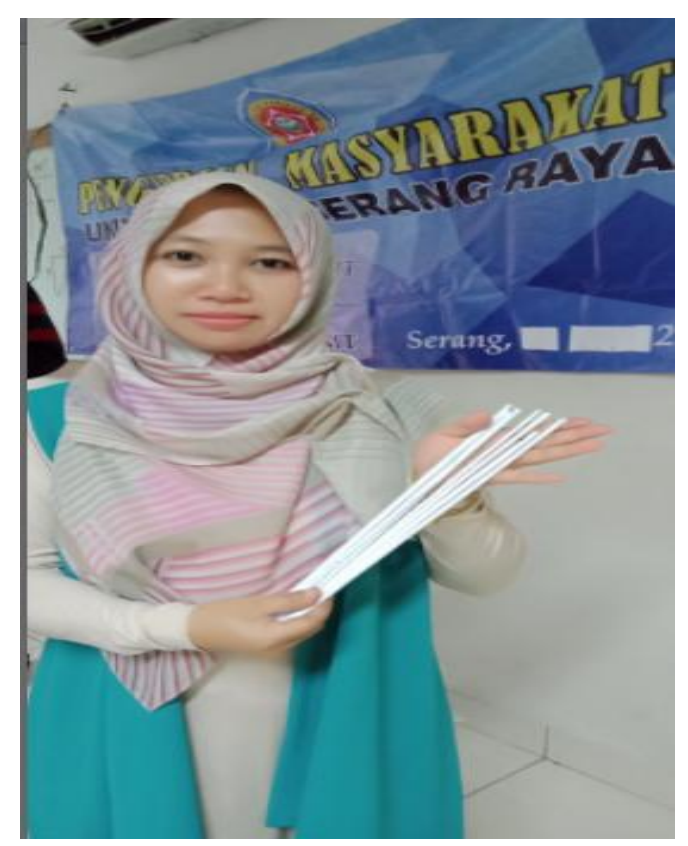

Gambar 10. Hasil Gulungan limbah kertas

\section{Produk Kerajinan Tangan}

Produk kerajinan tangan yang dihasilkan pada kegiatan pembekalan kepada mahasiswa KKM kelompok 26 dan 
kelompok 36 pada kecamatan Cikeusal dan kelompok 70 pada kecamatan Ciomas berupa kotak tisu dengan ukuran kecil. Untuk memberikan kesan warna yang lebih menarik dapat dilakukan dengan menambahkan proses pemberian vernis dan pengecatan. Produk kerajinan tangan pada kegiatan ini dapat dilihat pada Gambar 11.

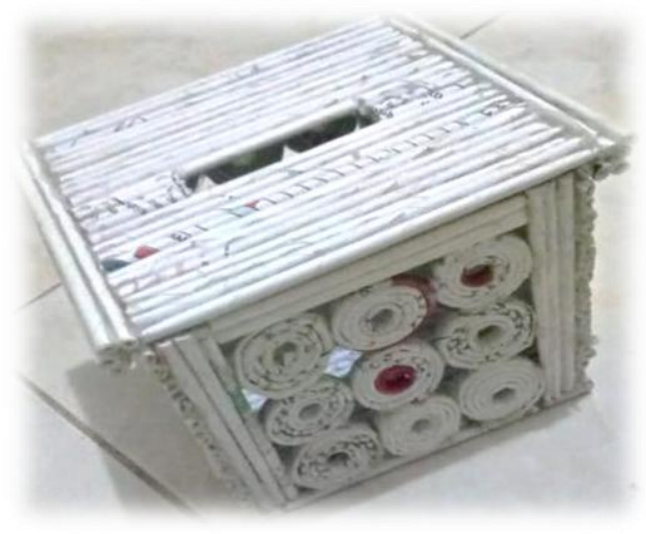

Gambar 11. Produk kerajinan tangan

\section{SIMPULAN}

Beberapa kesimpulan yang diperoleh dari kegiatan ini antara lain :

a. Kegiatan knowledge sharingyang dilaksanakan kepada mahasiswa KKM mampu memberikan pemahaman yang kemudian dapat dijadikan bekal dalam upaya memberdayakan masyakat tempat tujuan KKM, selanjutnya diharapkan kegiatan tersebut mampu menumbuhkan home industri dengan berbahan dasar limbah kertas agar dapat meningkatkan perekonomian masyarakat.

b. Melalui program knowledge sharing, mahasiswa KKM menperoleh peningkatan keterampilan khususnya dalam pengembangan produk dengan bahan dasar limbah kertas menjadi kerajinan tangan.

c. Luaran kegiatan ini adalah produk kerajinan tangan dengan berbahan dasar limbah kertas yaitu kotak tisu.

Rekomendasi untuk kegiatan selanjutnya adalah melakukan praktek pembuatan kerajinan tangan berupa kotak tisu kepada masyarakat kemudian melakukan pendampingan dalam pemasaran produk.

\section{DAFTAR PUSTAKA}

Direktorat Riset dan Pengabdian Kepada Masyarakat. 2018. Panduan Penelitian dan Kepijakan Kepada Masyarakat. Jakarta : Direktorat Riset dan Pengabdian Masyarakat.

Karwati, Lilis. (2015). Dampak program pelatihan kewirausahaan mandiri terhadap usaha Home Industri makanan ringan Desa Margaluyu Kecamatan Cikoneng Kabupaten Ciamis. Jurnal Empowerment, 3 (1), 102-125.

Priyono, Edi dan Muqorobin, Agus.2012. StudiLiteratur Terkait Perilaku Kewirausahaan (Study Literature on Entrepreneurial Behaviour). Fakultas Ekonomi Universitas Muhammadiyah Surakarta-Solo. 
Rahadjo, Mudjia. 2010, Hakikat dan Azas

Pengabdian Kepada Masyarakat, (Online), (https://www.uinmalang.ac.id/r/100501/hakikat-danasas-pengabdian-kepadamasyarakat.html, diakses 12 Agustus2019).

Rosmiati., Junias, Santosa, Tegus, Donny., dan Munawar. (2015). Sikap, Motivasi, dan Minat Berwirausaha Mahasiswa. Jurnal Manajemen dan Kewirausahaan, 17(1) : 21-30.

Yuslistyari, Indah, Eka. dan Djamal, Nugraheni. 2018. Pengembangan Kewirausahaan Mandiri Berbahan Dasar Melinjo Pada Ibu Rumah Tangga di Desa Angsana Kecamatan Mancak. Proceeding of Community Development, Vol 2 : 417-425.

Hisrich, R. (2001). Entrepreneurship Kewirausahaan. Jakarta: Salemba Empat. 